\title{
Antioxidative Effect of Dietary Flavonoid Isoquercitrin on Human Ovarian Granulosa Cells HGL5 In Vitro
}

\author{
Adriana KOLESAROVA ${ }^{1}$, Katarina MICHALCOVA ${ }^{1}$, Shubhadeep ROYCHOUDHURY ${ }^{2}$, \\ Simona BALDOVSKA ${ }^{3}$, Eva TVRDA ${ }^{1}$, Jaromir VASICEK ${ }^{1,4}$, Peter CHRENEK ${ }^{1,4}$, Luboslav \\ SANISLO ${ }^{\dagger}$, Vladimir KREN ${ }^{5}$ \\ ${ }^{\dagger}$ Deceased. \\ ${ }^{1}$ Department of Animal Physiology, Faculty of Biotechnology and Food Sciences, Slovak \\ University of Agriculture in Nitra, Nitra, Slovak Republic, ${ }^{2}$ Department of Life Science and \\ Bioinformatics, Assam University, Silchar, India, ${ }^{3}$ AgroBioTech Research Centre, Slovak \\ University of Agriculture in Nitra, Nitra, Slovak Republic, ${ }^{4}$ Research Institute for Animal \\ Production Nitra, National Agricultural and Food Centre, Lužianky, Slovak Republic, ${ }^{5}$ Institute of \\ Microbiology of the Czech Academy of Sciences, Prague, Czech Republic
}

Received March 29, 2021

Accepted June 24, 2021

Epub Ahead of Print September 10, 2021

\section{Summary}

This study aimed to examine the effect of dietary flavonoid isoquercitrin on ovarian granulosa cells using the immortalized human cell line HGL5. Cell viability, survival, apoptosis, release of steroid hormones $17 \beta$-estradiol and progesterone, and human transforming growth factor- $\beta 2$ (TGF- $\beta 2$ ) and TGF- $\beta 2$ receptor as well as intracellular reactive oxygen species (ROS) generation were investigated after isoquercitrin treatment at the concentration range of $5-100 \mu \mathrm{g} \cdot \mathrm{ml}^{-1}$. It did not cause any significant change $(p>0.05)$ in cell viability as studied by AlamarBlue assay in comparison to control. No significant change was observed $(p>0.05)$ in the proportion of live, dead and apoptotic cells as revealed by apoptotic assay using flow cytometry. Similarly, the release of $17 \beta$-estradiol, progesterone, TGF- $\beta 2$ and its receptor were not affected significantly $(p>0.05)$ by isoquercitrin as detected by ELISA, in comparison to control. Except for the highest concentration of $100 \mu \mathrm{g} \cdot \mathrm{ml}^{-1}$, which led to oxidative stress, isoquercitrin exhibited antioxidative activity at lower concentration used in the study $\left(5,10,25\right.$, and $\left.50 \mu \mathrm{g} \cdot \mathrm{ml}^{-1}\right)$ by hampering the production of intracellular ROS, in comparison to control, as detected by chemiluminescence assay $(p<0.05)$. Findings of the present study indicate an existence of the antioxidative pathway that involves inhibition of intracellular ROS generation by isoquercitrin in human ovarian granulosa cells.

\section{Key words}

Flavonoid • Granulosa cells • Antioxidant • Steroid hormones • Transforming growth factor

\section{Corresponding author}

A. Kolesárová, Department of Animal Physiology, Faculty of Biotechnology and Food Sciences, Slovak University of Agriculture in Nitra, Tr. A. Hlinku 2, 94976 Nitra, Slovak Republic. E-mail: Adriana.Kolesarova@uniag.sk

\section{Introduction}

Flavonoid glucosides such as quercetin and isoquercitrin occur widely in the plant kingdom and are among the most common flavonoids in the human diet. Isoquercitrin (quercetin-3-O- $\beta$-D-glucopyranoside) is commonly found in fruits, vegetables, cereals, various plant-derived foods and beverages such as tea and wine, as well as in medicinal herbs such as St. John's wort (Hypericum perforatum L.) (Paulke et al. 2006, Hasumura et al. 2004, Valentová et al. 2014). It has been reported in comprehensive database Phenol-Explorer, which notes polyphenol content in foods, that content of isoquercitrin ranges between $0.0067 \mathrm{mg}$ isoquercitrin/100 $\mathrm{g}$ (kiwi juice) and $41.95 \mathrm{mg}$ 
isoquercitrin/100 g (fresh black chokeberries - fruits of Aronia melanocarpa) (Neveu et al. 2010). Although this phytonutrient is widely distributed, it is very difficult to obtain a sufficient amount in a pure state for the food technology and pharmaceutical industry since isoquercitrin contents in plant materials are extremely low (Lu et al. 2013). In addition, considering the recommended daily dose of fruits and vegetables $(5 \times 100 \mathrm{~g})$ average daily intake of isoquercitrin could be estimated at 3-12 mg (Valentová et al. 2014). They possess neuroprotective, cardioprotective, chemopreventive, antiallergic, anti-inflammatory and antioxidant properties (Appleton 2010). Water soluble enzymatically modified isoquercitrin is generally regarded as safe for ingestion by the United States Food and Drug Administration (FDA 2007) and is also approved in Japan as a food additive (JFA 2007). On a daily basis, up to $4.9 \mathrm{mg} \cdot \mathrm{kg}^{-1}$ per day of enzymatically modified ( $\alpha$-glucosylated) isoquercitrin is acceptable (Valentová et al. 2014).

Dietary flavonoids, including isoquercitrin, possess neuroprotective, cardioprotective, chemopreventive, antiallergic, anti-inflammatory, and antioxidant properties (Appleton 2010). Its screening for clinical purposes has recently attracted a great deal of interest for a number of health issues including inflammation, atherosclerosis (Reuter et al. 2010), cancers of pancreas (Chen et al. 2015), liver (Huang et al. 2014), kidney (Buonerba et al. 2018), colon (Amado et al. 2014), bladder (Wu et al. 2017), ovary (Michalcova et al. 2019) as well as ROS-induced diseases particularly for mesenchymal stem cell transplantation therapy (Li et al. 2016).

Granulosa cells involved in the process of ovarian steroidogenesis and folliculogenesis are of clinical importance during oocyte development, and mainly secrete progesterone and estradiol, among various other factors. During menstrual cycle they turn into granulosa lutein (HGL) cells at the time of the luteinizing hormone (LH) surge. The HGL cells predominantly start secreting progesterone which is accompanied by a decline in estradiol production (Vander et al. 2001). HGL5 is an immortalized cell line derived from primary HGL cells after transformation with the E6 and E7 regions of human papillomavirus 16 (Rainey et al. 1994). They are capable of a quick growth and formation of large cultures apart from other qualities consistent with primary ovarian granulosa cells. HGL5 cell line forms an attractive model not only for investigating the mechanisms relating to steroid biosynthesis but also other pathways involved with HGL function (Rainey et al. 1994, Havelock et al. 2004, Bouraki et al. 2012). The present study aimed at examining the viability, survival, apoptosis, release of $17 \beta$-estradiol, progesterone, human transforming growth factor- $\beta 2$ (TGF- $\beta 2)$ and TGF- $\beta 2$ receptor, and intracellular ROS generation by HGL5 cells after isoquercitrin treatment at the concentrations of 5, 10, 25, 50, and $100 \mu \mathrm{g} \cdot \mathrm{ml}^{-1}$.

\section{Methods}

\section{Cell culture and treatment}

Isoquercitrin (quercetin 3-O- $\beta$-D-glucopyranoside, purity $96.5 \%$ ) was prepared by selective enzymatic derhamnosylation of rutin using recombinant $\alpha$-L-rhamnosidase from Aspergillus terreus (Weignerová et al. 2012). Purity of quercetin 3-O- $\beta$-D-glucopyranoside (isoquercitrin) was determined by HPLC by the method described in detail in the papers Weignerová et al. (2012) and Gerstorferová et al. (2012). Authenticity of this compound was determined by $1 \mathrm{H}$ and $13 \mathrm{C}$ NMR spectroscopy as detailed in the above papers. Immortalized human ovarian granulosa cells HGL5 (ABM ${ }^{\circledR}, \mathrm{BC}$, Canada) were cultured in Dulbecco's modified Eagle medium (Sigma-Aldrich, MO, USA) supplemented with $10 \%$ fetal bovine serum (SigmaAldrich, MO, USA), $1 \%$ antibiotics/antimycotic solution (Invitrogen, CA, USA). Cells were cultured in plates without (control group) or with isoquercitrin at concentrations of 5, 10, 25, 50, and $100 \mu \mathrm{g} \cdot \mathrm{ml}^{-1}$ for $24 \mathrm{~h}$. As a positive control $0.1 \%$ DMSO (dimethyl sulfoxide, Sigma Aldrich, St. Louis, MO, USA, $\geq 99.5 \%$ purity) was used, as previously described (Baldovská et al. 2020). All the procedures followed were in accordance with institutional guidelines.

\section{Cell viability}

Cell viability was examined using AlamarBlue (BioSource International, Nivelles, Belgium) assay (Michalcova et al. 2019). Human ovarian granulosa cells were seeded into 96-well microplates $\left(100 \mu 1\right.$ well $\left.^{-1}\right)$ at

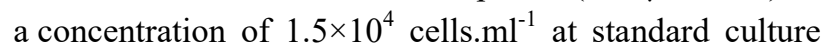
conditions of $5 \% \mathrm{CO}_{2}$ in air at $37^{\circ} \mathrm{C}$. Cells were grown in culture for $24 \mathrm{~h}$ without (control group) or with isoquercitrin $\left(5,10,25,50\right.$, and $\left.100 \mu \mathrm{g} \cdot \mathrm{ml}^{-1}\right)$, or with $0.1 \%$ DMSO (as positive control). Resazurin reduction (oxidized indigo blue state into the reduced pink state) was measured by recording the absorbance at $560 \mathrm{~nm}$ 
using a microplate reader (Multiskan FC, ThermoFisher Scientific, Finland) and expressed as percentage.

\section{Live, dead and apoptosis assay by flow cytometry}

Numbers of live, apoptotic and dead cells were detected by the rate of uptake and retention of certain dyes as described previously (Michalcova et al. 2019). Cells were seeded in 6-well culture plates at a density of $0.5 \times 10^{6}$ cells per well in culture medium (control) and/or supplemented with isoquercitrin (at concentrations 5, 10, 25, 50, and $100 \mu \mathrm{g} \cdot \mathrm{ml}^{-1}$ ) for $24 \mathrm{~h}$, whereas positive control received $0.1 \%$ DMSO. Apoptotic cells were measured by staining with specific nuclear fluorochrome Yo-Pro-1 (Molecular Probes, Lucerne, Switzerland) and specific membrane marker Annexin V-FITC (AnV; Annexin V Apoptosis Detection Kit, Canvax, Cordoba, Spain). Dead cells were measured by staining with propidium iodide (PI; Molecular Probes, Lucerne, Switzerland). Briefly, after centrifugation $(300 \times \mathrm{g}$ for $5 \mathrm{~min}$ ), cell pellets were adjusted to $1 \times 10^{6}$ cells per $\mathrm{ml}$ in PBS (without $\mathrm{Ca}$ and $\mathrm{Mg}$ ) and stained with $1 \mu \mathrm{l}$ of Yo-Pro-1 solution $\left(100 \mu \mathrm{mol} . \mathrm{l}^{-1}\right)$ for $15 \mathrm{~min}$ in dark at room temperature. Annexin $\mathrm{V}$ staining was done according to manufacturer's instructions. Cells were stained with $4 \mu \mathrm{l}$ of propidium iodide $\left(50 \mu \mathrm{g} \cdot \mathrm{ml}^{-1}\right)$ in each tube just prior to the analysis using flow cytometer (FACS Calibur, BD Biosciences, USA). At least 50000 events (cells) were analyzed in each sample and data analysis was done using Cell Quest Pro software (BD Biosciences, USA). Three different populations were identified using this assay: live unstained cells (Yo-Pro- ${ }^{-}$ $/ \mathrm{PI}^{-}$and $\mathrm{AnV}^{-} / \mathrm{PI}^{-}$), apoptotic cells (Yo-Pro- $1^{+} / \mathrm{PI}^{-}$and $\mathrm{AnV}^{+} / \mathrm{PI}^{-}$), and dead cells (only $\mathrm{PI}^{+}$) (Fig. 1).
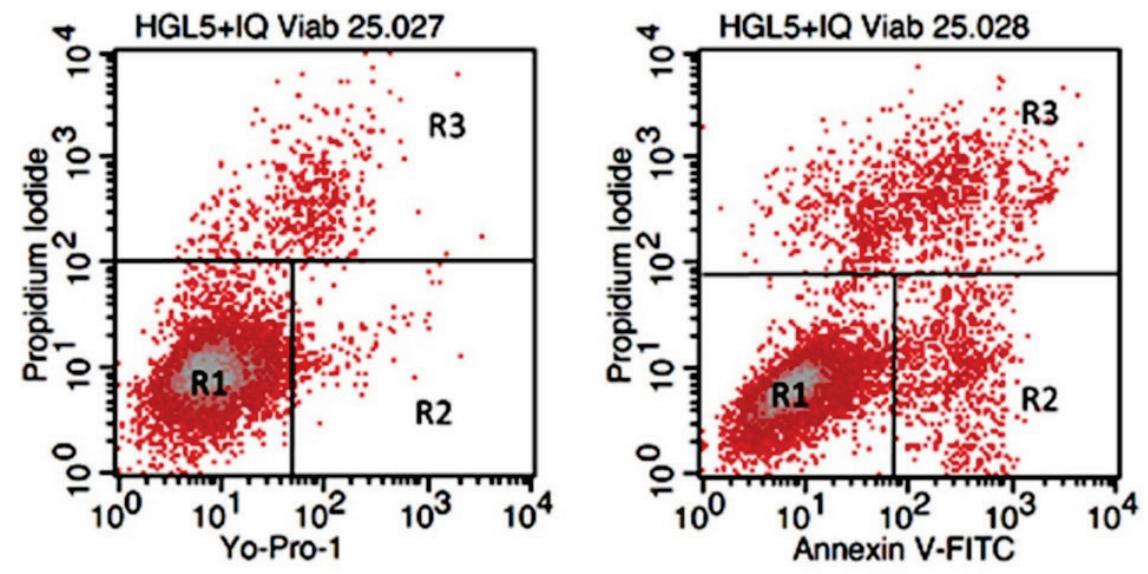

Fig. 1. Flow cytometry dot plots used for measuring the live, dead and apoptotic cells: R1 - Live unstained cells (Yo-Pro- $1^{-} / \mathrm{PI}^{-}$and $\mathrm{AnV}^{-} / \mathrm{PI}^{-}$), apoptotic cells (Yo-Pro- $1^{+} / \mathrm{PI}^{-}$and $\mathrm{AnV}^{+} / \mathrm{PI}^{-}$), and dead cells (only $\mathrm{PI}^{+}$).

\section{ELISA (enzyme-linked immunosorbent assay)}

Concentrations of secreted 17ß-estradiol, progesterone, TGF- $\beta 2$ and TGF- $\beta 2$ receptor were determined using ELISA kit (CUSABIO, Houston, USA) as described previously (Michalcova et al. 2019, Baldovská et al. 2020). Cells were re-seeded in 24-well culture plates at a density of $1 \times 10^{5}$ cells per well and then incubated in culture medium (control) and/or with isoquercitrin (at concentrations 5, 10, 25, 50, and $100 \mu \mathrm{g} \cdot \mathrm{ml}^{-1}$ ) for $24 \mathrm{~h}$ and the release of $17 \beta$-estradiol, progesterone, TGF- $\beta 2$ and TGF- $\beta 2$ receptor was measured. Briefly, antibody specific for $17 \beta$-estradiol, progesterone, TGF- $\beta 2$ and/or TGF- $\beta 2$ receptor was precoated on a microplate. Standards and samples were pipetted into the wells and any TGF- $\beta 2$ and/or TGF- $\beta 2$ receptor present was bound by the immobilized antibody. After removal of any unbound substances, abiotinconjugated antibody specific for 17 $\beta$-estradiol, progesterone, TGF- $\beta 2$ and TGF- $\beta 2$ receptor was added to the wells. After washing, avidin conjugated horseradish peroxidase was added to the wells. Washing was done to remove any unbound avidin-enzyme reagent, and substrate solution was added to the wells and color was developed in proportion to the amount of TGF- $\beta 2$ bound in the initial step. Color development was stopped and the intensity of the color was measured spectrophotometrically.

\section{ROS assay}

Intracellular ROS generation was assessed by chemiluminescence assay using luminol (5-amino-2,3dihydro-1,4-phthalazinedione; Sigma-Aldrich) as a probe (Michalcova et al. 2019, Sharma et al. 2017). Test samples consisted of $10 \mu \mathrm{l}$ luminol each $(5 \mathrm{mM})$ and $400 \mu \mathrm{l}$ experimental sample or control. Negative controls were prepared by replacing the HGL5 cell suspension 
with $400 \mu \mathrm{l}$ of culture medium each. Positive controls included $400 \mu \mathrm{l}$ of each medium, $10 \mu \mathrm{l}$ luminol and $50 \mu \mathrm{l}$ hydrogen peroxide $(30 \% ; 8.8 \mathrm{M}$; Sigma-Aldrich). Chemiluminescence was measured on 48 -well plates in 15 cycles of 1 min using the Glomax Multi+ Combined Spectro-Fluoro Luminometer (Promega Corporation, WI, USA). Results were expressed as relative light units (RLU). $\mathrm{s}^{-1} \cdot 10^{-6}$ cells (Michalcova et al. 2019, Tvrdá et al. 2016).

\section{Statistical analysis}

For statistical analysis, data were expressed as means with standard errors of means. All experiments were done in triplicate. One-way ANOVA along with Dunnett's tests were used to establish statistically significant differences at $\mathrm{p}<0.05$.

\section{Results}

In culture, HGL5 cells did not lose viability after isoquercitrin supplementation. As examined by AlamarBlue assay, isoquercitrin treatment did not cause any significant change $(\mathrm{p}>0.05)$ in the viability of human ovarian granulosa cells HGL5 at all the concentrations used in the study, as compared with control (Fig. 2). Similarly, as shown by flow cytometry analysis, isoquercitrin treatment did not cause any significant change $(p>0.05)$ in the proportion of live, dead and apoptotic HGL5 cells at all the concentrations used in the study (Table 1).
As detected by ELISA, isoquercitrin treatment did not cause any significant change $(p>0.05)$ neither in the release of steroid hormones 17 $\beta$-estradiol and progesterone by HGL5 cells (Fig. 3) as well as nor in the release of human TGF- $\beta 2$ and binding TGF- $\beta 2$ receptor (Fig. 4) at all of the concentrations used in the study. On the other hand, isoquercitrin treatment was capable of

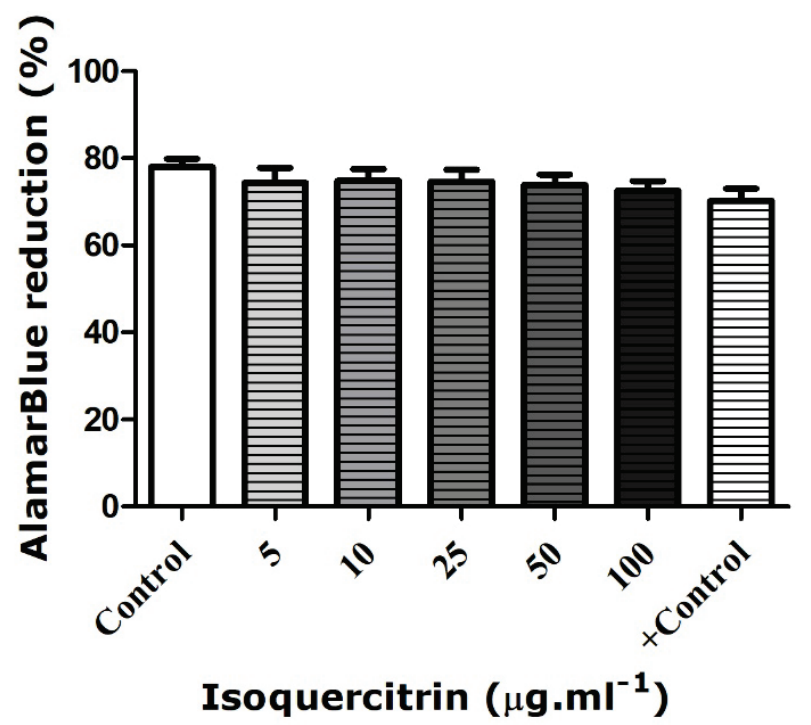

Fig. 2. Viability of human ovarian granulosa cells HGL5 without (Control) or with isoquercitrin treatment $(5,10,25,50$, $100 \mu \mathrm{g} \cdot \mathrm{ml}^{-1}$ ). Positive control (+Control) with $0.1 \%$ DMSO. Significance of differences between the groups was evaluated by One-way ANOVA followed by Dunnett's multiple comparison tests. The data are expressed as means \pm SEM. AlamarBlue assay.

Table 1. Proportion of live, dead and apoptotic HGL5 cells after isoquercitrin treatment at $5,10,25,50$, and $100 \mu$ g.ml ${ }^{-1}$ concentrations for $24 \mathrm{~h}$. Live cells remained unstained by specific nuclear fluorochrome Yo-Pro-1 and propidium iodide (PI) and specific membrane marker Annexin V-FITC (Yo-Pro-1/ $\mathrm{PI}^{-}$and $\mathrm{AnV}^{-} / \mathrm{PI}^{-}$), whereas dead cells were stained by propidium iodide (only $\mathrm{PI}^{+}$) and apoptotic cells were stained by specific nuclear fluorochrome Yo-Pro-1 and specific membrane marker Annexin V-FITC but unstained by propidium iodide (Yo-Pro- $1^{+} / \mathrm{PI}^{-}$and $\mathrm{AnV}^{+} / \mathrm{PI}^{-}$).

\begin{tabular}{|c|c|c|c|c|c|c|c|}
\hline $\begin{array}{l}\text { Parameter } \\
\text { Yo-Pro-1/PI }\end{array}$ & Control & 5 & 10 & $\begin{array}{c}25 \\
\mu \mathrm{g} . \mathrm{ml}^{-1}\end{array}$ & 50 & 100 & $\begin{array}{l}\text { Positive } \\
\text { control }\end{array}$ \\
\hline Live (\%) & $79.98 \pm 5.82$ & $80.94 \pm 5.64$ & $83.11 \pm 5.22$ & $82.63 \pm 5.45$ & $89.86 \pm 2.92$ & $84.96 \pm 3.45$ & $85.73 \pm 4.10$ \\
\hline Dead (\%) & $16.36 \pm 1.21$ & $15.48 \pm 1.38$ & $11.32 \pm 3.95$ & $12.45 \pm 3.04$ & $8.54 \pm 2.69$ & $10.49 \pm 2.97$ & $11.95 \pm 3.91$ \\
\hline Apoptotic (\%) & $5.73 \pm 1.88$ & $5.62 \pm 1.80$ & $5.57 \pm 1.95$ & $4.92 \pm 1.92$ & $3.98 \pm 1.20$ & $4.55 \pm 1.48$ & $4.88 \pm 1.31$ \\
\hline $\begin{array}{l}\text { Parameter } \\
\text { AnV/PI }\end{array}$ & Control & 5 & 10 & $\begin{array}{c}25 \\
\mu \mathrm{g} . \mathrm{ml}^{-1}\end{array}$ & 50 & 100 & $\begin{array}{l}\text { Positive } \\
\text { control }\end{array}$ \\
\hline Live (\%) & $81.54 \pm 7.65$ & $79.16 \pm 6.6$ & $78.20 \pm 9.80$ & $79.58 \pm 9.80$ & $89.90 \pm 2.81$ & $87.80 \pm 3.65$ & $85.07 \pm 3.75$ \\
\hline Dead (\%) & $18.85 \pm 6.77$ & $19.75 \pm 6.40$ & $25.14 \pm 5.86$ & $24.12 \pm 5.24$ & $10.18 \pm 1.08$ & $10.61 \pm 2.43$ & $12.91 \pm 3.47$ \\
\hline Apoptotic (\%) & $1.75 \pm 0.20$ & $1.89 \pm 0.25$ & $2.04 \pm 0.49$ & $1.52 \pm 0.36$ & $1.55 \pm 0.29$ & $1.60 \pm 0.33$ & $2.02 \pm 0.45$ \\
\hline
\end{tabular}


reducing intracellular ROS generation at concentrations of $5,10,25 \mu \mathrm{g} \cdot \mathrm{ml}^{-1}(\mathrm{p}<0.001)$ and $50 \mu \mathrm{g} \cdot \mathrm{ml}^{-1} \quad(\mathrm{p}<0.01)$ used in the study, as determined by chemiluminescence assay. However, the highest concentration of $100 \mu \mathrm{g} \cdot \mathrm{ml}^{-1}$ isoquercitrin led to oxidative stress resulting in an increase $(\mathrm{p}<0.05)$ in intracellular production of ROS (Fig. 5).
A

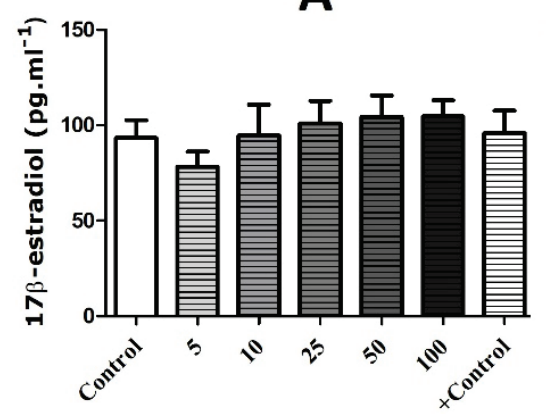

Isoquercitrin $\left(\mu \mathrm{g} \cdot \mathrm{ml}^{-1}\right)$

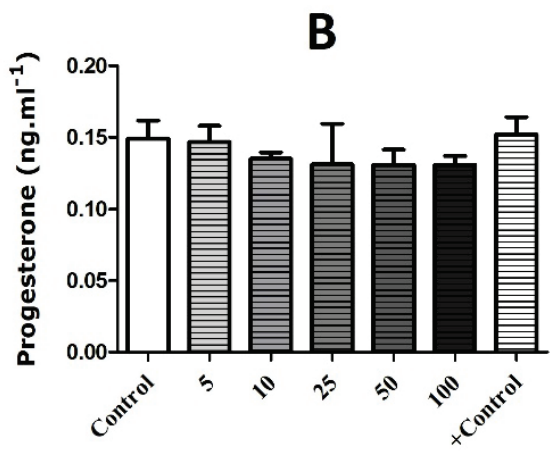

Isoquercitrin $\left(\mu \mathrm{g} \cdot \mathrm{ml}^{-1}\right)$
A

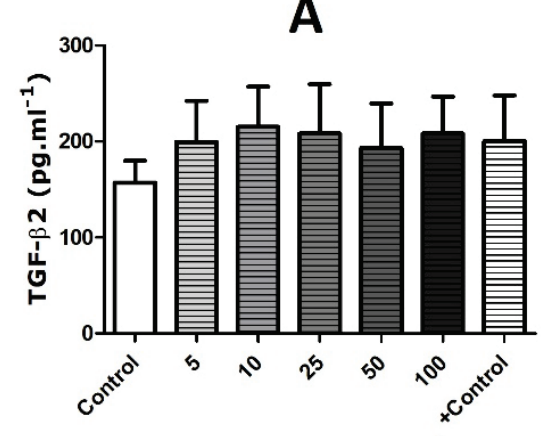

Isoquercitrin $\left(\mu \mathrm{g} \cdot \mathrm{ml}^{-1}\right)$

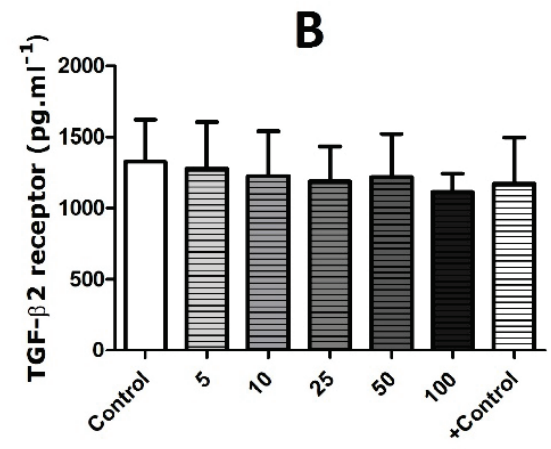

Isoquercitrin $\left(\mu \mathrm{g} \cdot \mathrm{ml}^{-1}\right)$
Fig. 3. Release of $17 \beta$-estradiol (A) and progesterone (B) by human ovarian granulosa cells HGL5 after treatment with isoquercitrin $(5,10$, 25, 50, $\quad 100 \mu \mathrm{g} \cdot \mathrm{ml}^{-1}$ ). Control represents culture medium without isoquercitrin; positive control (+Control) means culture medium enriched by $0.1 \%$ DMSO. Significance of differences between the groups was evaluated by One-way ANOVA followed by Dunnett's multiple comparison tests. The data are expressed as means \pm SEM. ELISA.

Fig. 4. Release of TGF- $\beta 2$ (A) and TGF- $\beta 2$ receptor (B) by human ovarian granulosa cells HGL5 after treatment with isoquercitrin $(5,10$, 25, 50, $\quad 100 \mu \mathrm{g} \cdot \mathrm{ml}^{-1}$ ). Control represents culture medium without isoquercitrin; positive control (+Control) means culture medium enriched by $0.1 \%$ DMSO. Significance of differences between the groups was evaluated by One-way ANOVA followed by Dunnett's multiple comparison tests. The data are expressed as means \pm SEM. ELISA.

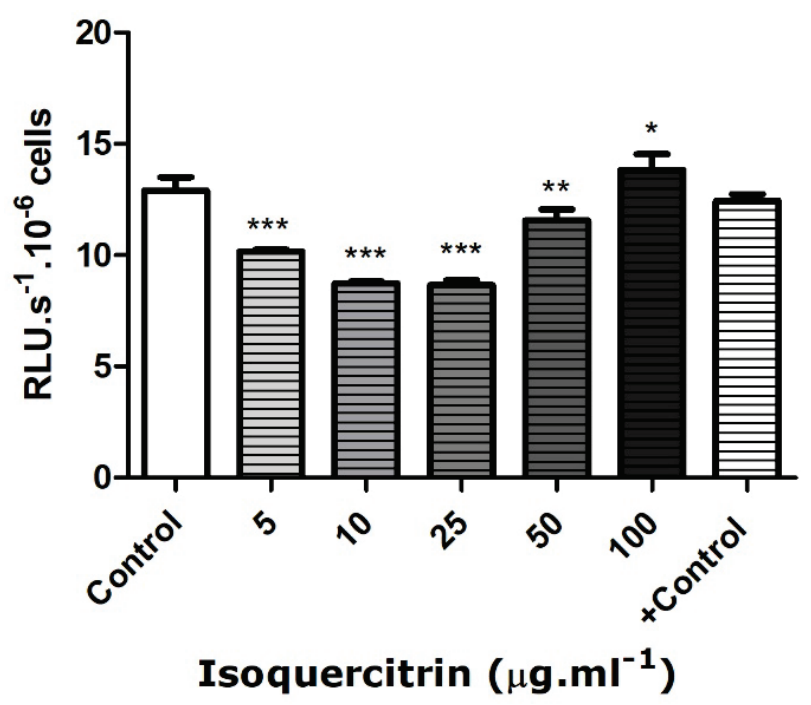

Fig. 5. Intracellular ROS generation by human ovarian granulosa cells HGL5 after treatment with isoquercitrin $(5,10,25,50$, $100 \mu \mathrm{g} \cdot \mathrm{ml}^{-1}$ ). Control represents culture medium without isoquercitrin; positive control (+Control) means culture medium enriched by $0.1 \%$ DMSO. Significance of differences between the groups was evaluated by One-way ANOVA followed by Dunnett's multiple comparison tests. The data are expressed as means $\pm \mathrm{SEM}$. Chemiluminescence assay. $* \mathrm{p}<0.05, * * \mathrm{p}<0.01, * * * \mathrm{p}<0.001$.

\section{Discussion}

In the ovarian follicle, granulosa cells constitute the principal somatic cell type, which is involved in the process of steroidogenesis and folliculogenesis (Ai et al. 2019). Based on the phase of development, granulosa cells secrete a number of factors. These cells express follicle stimulating hormone (FSH) receptors during the first half of the menstrual cycle. Under the influence of FSH granulosa cells further express aromatase that converts androgens, produced in theca cells, to estradiol. Thereafter the granulosa cells start predominantly secreting progesterone during the LH surge as they turn into hGL cells (Vander et al. 2001). In the present study, we used HGL5 cells a suitable cellular model to investigate the effect of dietary bioflavonoid isoquercitrin at the concentrations ranging from $5-100 \mu \mathrm{g} \cdot \mathrm{ml}^{-1}$ on cell viability, survival, apoptosis, release of $17 \beta$-estradiol, progesterone and TGF- $\beta 2$ and TGF- $\beta 2$ receptor as well as the ROS production. To our knowledge, this is the first report which has looked into the influence of 
isoquercitrin on ovarian granulosa cells.

Similar to our findings, treatment with isoquercitrin did not affect the viability of human ovarian cancer cells OVCAR-3 as determined by AlamarBlue assay (Michalcova et al. 2019). Furthermore, concentrations of 25,50 , and $100 \mu \mathrm{mol}^{-1} \mathrm{l}^{-1}$ isoquercitrin isolated from the aerial parts of Hyptis fasciculata did not cause any change in the viability of human brain cancer cells after 24, 48, and $72 \mathrm{~h}$ (Amado et al. 2009). When cultured with isoquercitrin at 50,100 and $200 \mu \mathrm{M}$ concentrations for $72 \mathrm{~h}$, MTT assay also showed no change of viability in rat hepatoma cells H4IIE (Zhou et al. 2014). Isolated from Acer okamotoanum, isoquercitrin at the concentration range of 1-10 $\mu \mathrm{g} \cdot \mathrm{ml}^{-1}$ did not affect the viability of SH-SY5Y human neuronal cells, too. On the other hand, isoquercitrin was capable of protecting the cells by increasing their viability against hydrogen peroxide $\left(\mathrm{H}_{2} \mathrm{O}_{2}\right)$-induced oxidative stress (Kim et al. 2019).

Similar to the findings of the present study, isoquercitrin, isolated from the aerial parts of Hyptis fasciculata, did not affect caspase-3 dependent apoptosis at concentrations up to $100 \mathrm{mmol} . \mathrm{l}^{-1}$ in human brain cancer cells (Amado et al. 2009). In another previous study, isoquercitrin was found to cause down-regulation of apoptotic protein expression such as cleaved caspase9, -3 , PARP, and p53. It also inhibited $\mathrm{H}_{2} \mathrm{O}_{2}$-induced apoptosis in the cellular system and the treatment further showed attenuation of apoptotic rate in the Hoechst 33342/PI double staining and Annexin V-FITC/PI staining. Anti-apoptotic effect was further associated with the Akt/GSK3b signaling pathway, and isoquercitrin was recommended for clinical use owing to its capability to interfere with the progression of endothelial injuryassociated cardiovascular disease (Zhu et al. 2016). On the other hand, potential clinical use of isoquercitrin in cancer cells is believed to be mediated by its proapoptotic property. Therapeutic doses of isoquercitrin extracted from Bidens pilosa L. retarded proliferation, induced apoptosis, and the cell cycle was arrested in the G1 phase in human bladder cancer cells 5637 and T24 (Chen et al. 2016). Isolated from Bidens bipinnata L. extract, it also promoted apoptosis, inhibited cell proliferation, and blocked the cell cycle via the mitogenactivated protein kinase (MAPK) signaling pathway in human liver cancer cells HepG2 and Hep3B (Huang et al. 2014).

Recently, our research group has reported the production of steroid hormones by HGL5 cells and that dry pomegranate extract affected the release of 17ß-estradiol when cultured for $24 \mathrm{~h}$ (Baldovska et al. 2019). Similarly, previous studies also showed secretion of estradiol and progesterone by HGL cells (Rainey et al. 1994, Havelock et al. 2004). However, it has been reported, that the HGL5 cell line is not responsive to FSH because of the lack of gonadotropin receptors, although upon stimulation by the agonists of the protein kinase-A pathway forskolin (a weight loss supplement prepared from the roots of Coleus forskohlii) and dibutyryl cAMP the HGL5 cells were found to produce progesterone (Rainey et al. 1994). As a potent luteinizing granulosa cell survival factor, progesterone was earlier found to promote the expression of epidermal growth factor family member amphiregulin and epiregulin thereby helping maintain the viability of luteinizing granulosa cells in primates. This has been considered as one of the possible mechanisms as to how progesterone promotes corpus luteum formation in the event of fertilization (Puttabyatappa et al. 2013). Members of the TGF- $\beta$ superfamily are expressed by ovarian somatic cells and oocytes are involved in folliculogenesis, including intraovarian control mechanisms, follicular assembly, growth, differentiation and progression, and thus fertility (Knight et al. 2006, Trombly et al. 2009). Another study conducted to explore the effects of the TGF- $\beta$ superfamily members and their receptors on human granulosa cells during folliculogenesis showed expression of TGF- $\beta$ superfamily members and their receptors in a human nonluteinized granulosa cell line $\mathrm{HGrC1}$, including the type I and II receptors (Iwase et al. 2012). Previous studies have reported the production of TGF- $\beta 1$ and TGF- $\beta 2$ by ovarian cells (Puttabyatappa et al. 2013, Roy et al. 1994, Bristol et al. 2004). In the present study, HGL 5 cells have also been able to release both TGF- $\beta 2$ and TGF- $\beta 2$ receptor although isoquercitrin did not have any impact on their expression. Furthermore, Michalcova et al. (2019) has reported, that the release of human TGF- $\beta 1$ and binding of TGF- $\beta 1$ receptor by ovarian cancer cells was not affected by isoquercitrin.

Notably, the results of the present study on the effect of isoquercitrin on human granulosa cells indicate, that isoquercitrin could scavenge intracellular ROS production at lower concentrations and is able to decrease oxidative stress in HGL5 cells in vitro. Isoquercitrin isolated from Thuja orientalis was able to scavenge reactive oxygen species $\left(\mathrm{H}_{2} \mathrm{O}_{2}, \cdot \mathrm{OH}\right.$ and $\left.\mathrm{O} 2 \cdot-\right)$ as demonstrated by staining of cultures as well as the generation of individual radical species at $50 \mu \mathrm{M}$ 
concentration (Jung et al. 2010). Isolated from Acer okamotoanum, isoquercitrin was able to ameliorate $\mathrm{H}_{2} \mathrm{O}_{2}$-induced oxidative stress by successfully inhibiting the production of ROS in human neuronal cells at a concentration of $10 \mu \mathrm{g} \cdot \mathrm{ml}^{-1}$. The antioxidant property of isoquercitrin molecule was believed to be attributed by its catechol moiety in B ring as the biological activity of flavonoids depend on the number and position of $-\mathrm{OH}$ as well as the presence of sugar. Based on the findings, isoquercitrin has been considered useful as a preventive and therapeutic agent for neurodegenerative diseases including Alzheimer's disease (Kim et al. 2019). On the other hand, in rat hippocampal neuronal cells pretreatment with isoquercitrin at 25,50 and $100 \mu \mathrm{g} \cdot \mathrm{ml}^{-1}$ for $24 \mathrm{~h}$ prior to $4 \mathrm{~h}$ of oxygen glucose deprivation and $24 \mathrm{~h}$ of normoxia was not sufficient to reduce the generation of ROS although a concentration-dependent trend of decline was noted (Chen et al. 2017). Antioxidant activity of isoquercitrin at $10-100 \mu \mathrm{M}$ concentration range was also evident by the activation of glutathione peroxidase enzyme apart from the reduction of malondiadehyde levels in 6-hydroxydopamine-induced PC-12 cells and the reduction of superoxide dismutase activity (Magalingam et al. 2016), which, in turn, is believed to catalyze the detoxification of detrimental superoxide radicals to less toxic molecules thus leading to attenuation of oxidative stress (Duong et al. 2008). These findings further support the clinical potential of isoquercitrin in the management of oxidative stress in neurodegenerative diseases.

It is well known that $\mathrm{ROS}$ (especially $\cdot \mathrm{O}_{2}{ }^{-}$ radical anions and $\cdot \mathrm{OH}$ radicals) are generated via $\mathrm{Fe}^{2+}$ catalysis and their generation can be reduced by $\mathrm{Fe}^{2+}$ binding (or chelating). This indirectly elicits the antioxidant activity of many flavonoids including the flavonoid glucoside isoquercitrin, which can be exploited in the therapeutic approaches for management of many diseases related to ROS, including several neurodegenerative diseases such as Alzheimer's disease, Parkinson's disease, ophthalmic diseases such as glaucoma, and several types of cancers, among others (Fang and Zheng 2002, Devos et al. 2014).

In the light of the previous findings on the role of isoquercitrin on various cells, tissues and cell lines of both healthy and disease models, the findings of the present study on human ovarian granulosa cells HGL5 indicate that isoquercitrin may be able to protect the ovarian functions from oxidative stress through a pathway involving the inhibition of intracellular ROS generation. Further investigations may prove very useful in confirming the hypothesis of the protective role of isoquercitrin at proper therapeutic concentrations against ovarian aging as well as other pathologies of the ovary whose etiology involves oxidative stress.

\section{Conflict of Interest}

There is no conflict of interest.

\section{Acknowledgements}

This work was supported by the Ministry of Education, Science, Research and Sport of the Slovak Republic (projects APVV-18-0312, APVV-16-0170, DS-FR-190049, VEGA 1/0266/20), The Excellent scientific team "Center of Animal Reproduction (CeRA)", the Operational program Integrated Infrastructure within the project: Creation of nuclear herds of dairy cattle with a requirement for high health status through the use of genomic selection, innovative biotechnological methods, and optimal management of breeding, NUKLEUS 313011V387, cofinanced by the European Regional Development Fund, and AgroBioTech Research Centre built in accordance with the project Building, “AgroBioTech" Research Centre ITMS 26220220180.

\section{References}

AI A, TANG Z, LIU Y, YU S, LI B, HUANG H, WANG X, CAO Y, ZHANG W: Characterization and identification of human immortalized granulosa cells derived from ovarian follicular fluid. Exp Ther Med 18: 2167-2177, 2019. https://doi.org/10.3892/etm.2019.7802

AMADO NG, CERQUEIRA DM, MENEZES FS, DA SILVA JF, NETO VM, ABREU JG: Isoquercitrin isolated from hyptis fasciculata reduces glioblastoma cell proliferation and changes beta-catenin cellular localization. Anticancer Drugs 20: 543-552, 2009. https://doi.org/10.1097/CAD.0b013e32832d1149

AMADO NG, PREDES D, FONSECA BF, CERQUEIRA DM, REIS AH, DUDENHOEFFER AC, BORGES HL, MENDES FA, ABREU JG: Isoquercitrin suppresses colon cancer cell growth in vitro by targeting the wnt/ $\beta$ catenin signaling pathway. J Biol Chem 289: 35456-35467, 2014. https://doi.org/10.1074/jbc.M114.621599 
APPLETON J: Evaluating the bioavailability of isoquercetin. Nat Med 2: 1-6, 2010.

ARUMUGAM S, BANDIL K, PROKSCH P, MURUGIYAN K, BHARADWAJ M: Effects of A. marina-derived isoquercitrin on TNF-related apoptosis-inducing ligand receptor (TRAIL-R) expression and apoptosis induction in cervical cancer cells. Appl Biochem Biotechnol 182: 697-707, 2017. https://doi.org/10.1007/s12010-016-2355-6

BALDOVSKÁ S, MARUNIAKOVÁ N, SLÁMA P, PAVLÍK A, KOHÚT L, KOLESÁROVÁ A: Efficacy of phytonutrients from pomegranate peel on human ovarian cells in vitro. J Microbiol Biotechnol Food Sci 10: 511-516, 2020. https://doi.org/10.15414/jmbfs.2020.10.3.511-516

BALDOVSKA S, MICHALCOVA K, HALENAR M, CARBONELL-BARRACHINA AA, KOLESAROVA A: Polyphenol-rich pomoegranate extract as a potential modulator of steroidogenesis in human ovarian cells. J Microbiol Biotechnol Food Sci 8: 1343-1346, 2019. https://doi.org/10.15414/jmbfs.2019.8.6.1343-1346

BOURAKi G, METALLiNOU C, SimOpoulou M, CHARALABOpOUlOS K, ASIMAKOPOULOS B: Comparison of nine media in the culture of human ovarian granulosa lutein cells. In Vivo 26: 823-825, 2012.

BRISTOL SK, WOODRUFF TK: Follicle-restricted compartmentalization of transforming growth factor beta superfamily ligands in the feline ovary. Biol Reprod 70: 846-859, 2004. https://doi.org/10.1095/biolreprod.103.021857

BUONERBA C, DE PLACIDO P, BRUZZESE D, PAGLIUCA M, UNGARO P, BOSSO D, RIBERA D, IACCARINO S, SCAFURI L, LIOTTI A: Isoquercetin as an adjunct therapy in patients with kidney cancer receiving first-line sunitinib (quasar): results of a phase I trial. Front Pharmacol 9: 189, 2018. https://doi.org/10.3389/fphar.2018.00189

CHEN Q, LI P, LI P, XU Y, LI Y, TANG B: Isoquercitrin inhibits the progression of pancreatic cancer in vivo and in vitro by regulating opioid receptors and the mitogen-activated protein kinase signalling pathway. Oncol Rep 33: 840-848, 2015. https://doi.org/10.3892/or.2014.3626

CHEN F, CHEN X, YANG D, CHE X, WANG J, LI X, ZHANG Z, WANG Q, ZHENG W, WANG L, SONG X: Isoquercitrin inhibits bladder cancer progression in vivo and in vitro by regulating the PI3K/Akt and PKC signaling pathways. Oncol Rep 36: 165-172, 2016. https://doi.org/10.3892/or.2016.4794

CHEN M, DAI LH, FEI A, PAN SM, WANG HR: Isoquercetin activates the ERK1/2-NRF2 pathway and protects against cerebral ischemia-reperfusion injury in vivo and in vitro. Exp Ther Med 13: 1353-1359, 2017. https://doi.org/10.3892/etm.2017.4093

DEVOS D, MOREAU C, DEVEDJIAN JC, KLUZA J, PETRAULT M, LALOUX C, JONNEAUX A, RYCKEWAERT G, GARÇON G, ROUAIX N: Targeting chelatable iron as a therapeutic modality in Parkinson's disease. Antioxid Redox Signal 21: 195-210, 2014. https://doi.org/10.1089/ars.2013.5593

DUONG TT, ANTAO S, ELLIS NA, MYERS SJ, WITTING PK: Supplementation with a synthetic polyphenol limits oxidative stress and enhances neuronal cell viability in response to hypoxia-re-oxygenation injury. Brain Res 1219: 8-18, 2008. https://doi.org/10.1016/j.brainres.2008.04.044

FANG YZ, ZHENG RL: Reactive oxygen species. In: Theory and Application of Free Radical Biology. 1st Edition. FANG YZ, ZHENG RL (eds), Scientific Press, Beijing, China, 2002, pp 98-124.

FDA: Agency response letter gras notice no. Grn00220 [alpha-glycosyl isoquercitrin]. U.S. Food and drug administration center for food safety and applied nutrition, 2007.

GERSTORFEROVÁ D, FLIEDROVÁ B, HALADA P, MARHOL P, KŘEN V, WEIGNEROVÁ L: Recombinant $\alpha-1-$ rhamnosidase from Aspergillus terreus in selective trimming of rutin. Process Biochem 47: 828-835, 2012. https://doi.org/10.1016/j.procbio.2012.02.014

HASUMURA M, YASUHARA K, TAMURA T, IMAI T, MITSUMORI K, HIROSE M: Evaluation of the toxicity of enzymatically decomposed rutin with 13-weeks dietary administration to Wistar rats. Food Chem Toxicol 42: 439-444, 2004. https://doi.org/10.1016/j.fct.2003.10.006

HAVELOCK JC, RAINEY WE, CARR BR: Ovarian granulosa cell lines. Mol Cell Endocrinol 228: 67-78, 2004. https://doi.org/10.1016/j.mce.2004.04.018

HUANG G, TANG B, TANG K, DONG X, DENG J, LIAO L, LIAO Z, YANG H, HE S: Isoquercitrin inhibits the progression of liver cancer in vivo and in vitro via the MAPK signalling pathway. Oncol Rep 31: 2377-2384, 2014. https://doi.org/10.3892/or.2014.3099 
IWASE AB, KIYONO T, TAKIKAWA S, GOTO M, NAKAMURA T, NAGATOMO Y, NAKAHARA T, KOTANI T, KOBAYASHI H: Establishment of a human nonluteinized granulosa cell line that transitions from the gonadotropin-independent to the gonadotropin-dependent status. Endocrinology 153: 2851-2860, 2012. https://doi.org/10.1210/en.2011-1810

JFA: Japanese Specifications and Standards for Food Additives. 8. Tokyo: Japan, 2007.

JUNG SH, KIM BJ, LEE EH, OSBORNE NN: Isoquercitrin is the most effective antioxidant in the plant Thuja orientalis and able to counteract oxidative-induced damage to a transformed cell line (RGC-5 cells). Neurochem Int 57: 713-721, 2010. https://doi.org/10.1016/j.neuint.2010.08.005

KIM JH, QUILANTANG NG, KIM HY, LEE S, CHO EJ: Attenuation of hydrogen peroxide-induced oxidative stress in SH-SY5Y cells by three flavonoids from Acer okamotoanum. Chem Papers 73: 1135-1144, 2019. https://doi.org/10.1007/s11696-018-0664-7

KNIGHT PG, GLISTER C: TGF-beta superfamily members and ovarian follicle development. Reproduction 132: 191-206, 2006. https://doi.org/10.1530/rep.1.01074

LI X, JIANG Q, WANG T, LIU J, CHEN D: Comparison of the antioxidant effects of quercitrin and isoquercitrin: Understanding the role of the 6"-oh group. Molecules 21: 1246, 2016. https://doi.org/10.3390/molecules21091246

LU Z, WANG J, LIN S, ZHAN Y: Degradation of rutin into isoquercitrin by Bacillus litoralis strain C44. IOSR J Engin 2: 1154-1161, 2013. https://doi.org/10.9790/3021-020511541161

MAGALINGAM KB, RADHAKRISHNAN A, HALEAGRAHARA N: Protective effects of quercetin glycosides, rutin, and isoquercetrin against 6-hydroxydopamine (6-OHDA)-induced neurotoxicity in rat pheochromocytoma (PC-12) cells. Int J Immunopathol Pharmacol 29: 30-39, 2016. https://doi.org/10.1177/0394632015613039

MICHALCOVA K, ROYCHOUDHURY S, HALENAR M, TVRDA E, KOVACIKOVA E, VASICEK J, CHRENEK P, BALDOVSKA S, SANISLO L, KREN V, KOLESAROVA A: In vitro response of human ovarian cancer cells to dietary bioflavonoid isoquercitrin. J Environ Sci Health B 54: 752-757, 2019. https://doi.org/10.1080/03601234.2019.1633214

NEVEU V, PEREZ-JIMÉNEZ J, VOS F, CRESPY V, DU CHAFFAUT L, MENNEN L, KNOX C, EISNER R, CRUZ J, WISHART D, SCALBERT A: Phenol-Explorer: an online comprehensive database on polyphenol contents in foods. Database (Oxford) 2010: bap024, 2010. https://doi.org/10.1093/database/bap024

PAULKE A, SCHUBERT-ZSILAVECZ M, WURGLICS M: Determination of St. John's wort flavonoid-metabolites in rat brain through high performance liquid chromatography coupled with fluorescence detection. J Chromatogr B Analyt Technol Biomed Life Sci 832: 109-113, 2006. https://doi.org/10.1016/j.jchromb.2005.12.043

PUTTABYATAPPA M, BROGAN RS, VANDEVOORT CA, CHAFFIN CL: EGF-like ligands mediate progesterone's anti-apoptotic action on macaque granulosa cells. Biol Reprod 88: 1-10, 2013. https://doi.org/10.1095/biolreprod.112.103002

RAINEY WH, SAWETAWAN C, SHAY JW, MICHAEL MD, MATHIS JM, KUTTEH W, BYRD W, CARR BR: Transformation of human granulosa cells with the e6 and e7 regions of human papillomavirus. J Clin Endocrinol Metab 78: 705-710, 1994. https://doi.org/10.1210/jcem.78.3.8126145

REUTER S, GUPTA SC, CHATURVEDI MM, AGGARWAL BB: Oxidative stress, inflammation, and cancer: How are they linked? Free Radic Biol Med 49: 1603-1616, 2010. https://doi.org/10.1016/j.freeradbiomed.2010.09.006

ROY SK, HUGHES J: Ontogeny of granulosa cells in the ovary: Lineage-specific expression of transforming growth factor beta 2 and transforming growth factor beta 1. Biol Reprod 51: 821-830, 1994. https://doi.org/10.1095/biolreprod51.5.821

SHARMA R, ROYCHOUDHURY S, SINGH N, SARDA Y: Methods to measure reactive oxygen species (ROS) and total antioxidant capacity (TAC) in the reproductive system. In: Oxidative Stress in Human Reproduction. AGARWAL A, SHARMA R, GUPTA S, HARLEV A, AHMAD G, DU PLESSIS SS, ESTEVES SC, WANG SW, DURAIRAJANAYAGAM D (eds), Springer, Cham, 2017, pp 17-46. https://doi.org/10.1007/978-3-31948427-3 2

TROMBLY DJ, WOODRUFF TK, MAYO KE: Roles for transforming growth factor beta superfamily proteins in early folliculogenesis. Semin Reprod Med 27: 14-23, 2009. https://doi.org/10.1055/s-0028-1108006 
TVRDÁ E, TUŠIMOVÁ E, KOVÁČIK A, PAÁL D, GREIFOVÁ H, ABDRAMANOV A, LUKÁČ N: Curcumin has protective and antioxidant properties on bull spermatozoa subjected to induced oxidative stress. Anim Reprod Sci 172: 10-20, 2016. https://doi.org/10.1016/j.anireprosci.2016.06.008

VALENTOVÁ K, VRBA J, BANCÍŘOVÁ M, ULRICHOVÁ J, KŘEN V: Isoquercitrin: Pharmacology, toxicology, and metabolism. Food Chem Toxicol 68: 267-682, 2014. https://doi.org/10.1016/j.fct.2014.03.018

VANDER A, SHERMAN J, LUCIANO D, TSAKOPOULOS M: The mechanisms of body function. In: Human Physiology: 8th edition. PASCHALIDIS PH (ed.), Medical Editions, Athens, 2001, pp 860-872.

WEIGNEROVÁ L, MARHOL P, GERSTORFEROVÁ D, KŘEN V: Preparatory production of quercetin-3- $\beta$-dglucopyranoside using alkali-tolerant thermostable $\alpha$-l-rhamnosidase from aspergillus terreus. Bioresour Technol 115: 222-227, 2012. https://doi.org/10.1016/j.biortech.2011.08.029

WU P, LIU S, SU J, CHEN J, LI L, ZHANG R, CHEN T: Apoptosis triggered by isoquercitrin in bladder cancer cells by activating the AMPK-activated protein kinase pathway. Food Funct 8: 3707-3722, 2017. https://doi.org/10.1039/C7FO00778G

XIE W, WANG M, CHEN C, ZHANG X, MELZIG MF: Hepatoprotective effect of isoquercitrin against acetaminophen-induced liver injury. Life Sci 152: 180-189, 2016. https://doi.org/10.1016/j.lfs.2016.04.002

ZHOU J, YOSHITOMI H, LIU T, ZHOU B, SUN W, QIN L, GUO X, HUANG L, WU L, GAO M: Isoquercitrin activates the amp-activated protein kinase (AMPK) signal pathway in rat h4iie cells. BMC Complement Altern Med 14: 42, 2014. https://doi.org/10.1186/1472-6882-14-42

ZHU M, LI J, WANG K, HAO X, GE R, LI Q: Isoquercitrin inhibits hydrogen peroxide-induced apoptosis of ea.Hy926 cells via the PI3K/AKT/GSK3 $\beta$ signaling pathway. Molecules 21: 356, 2016. https://doi.org/10.3390/molecules21030356 